\title{
Langtímahorfur sjúklinga með bráða kransæðastíflu
}

\author{
Einar Logi Snorrason ${ }^{1}$ læknir \\ Bergrós Kristín Jóhannesdóttir ${ }^{2}$ læknir \\ Thor Aspelund ${ }^{3}$ tölfræðingur \\ Vilmundur Guðnason ${ }^{1,3}$ læknir \\ Karl Andersen ${ }^{1,4}$ læknir
}

\begin{abstract}
'Læknadeild Háskóla Íslands, ²Haukeland Universitetssjukehus, Bergen,
\end{abstract} ${ }^{3}$ Hjartavernd, ${ }^{4}$ hjartadeild 14EG Landspítala.

Fyrirspurnum svarar Karl Andersen, andersen@landspitali.is

\section{Inngangur}

Hjarta- og æðasjúkdómar eru algengasta dánarorsök í heiminum í dag. ${ }^{1,2}$ Árið 2015 dóu yfir 7,4 milljónir manna af völdum blóðpurrðarhjartasjúkdóma, eða um 13\% allra dauðsfalla. ${ }^{3}$ Í Evrópu eru blóðpurrðarhjartasjúkdómar orsakavaldur 21\% dauðsfalla meðal kvenna og 20\% dauðsfalla meðal karla. ${ }^{4}$ Á Íslandi hefur nýgengi pessara sjúkdóma lækkað verulega á síðustu árum, eða um 66,5\%, og samhliða pví hefur dánartíðni af völdum peirra lækkað um $86 \%$ á tímabilinu 1981-2015.

Horfur peirra sem fá kransæðastíflu fer sömuleiðis batnandi og skýrist pað að miklu leyti af bættri lyfjameðferð og tækniframförum. ${ }^{6}$ Um miðja síðustu öld dó priðji hver sjúklingur með bráða kransæðastíflu áður en hann náði að útskrifast heim af sjúkrahúsi en nú er dánartíðni STEMI-sjúklinga um 6-7\% 30 dögum eftir innlögn. ${ }^{5}$

Prátt fyrir lækkandi nýgengi blóðpurrðarhjartasjúkdóma á Íslandi hefur hlutfall NSTEMI af öllum hjartaáföllum hækkað á undanförnum árum. Petta má rekja til næmari greiningaraðferða og breytinga í áhættupáttum. ${ }^{7}$ Nýgengi NSTEMI er almennt hærra en STEMI pó tölur séu á reiki milli landa., ${ }^{4,-11}$ Litlar upplýsingar eru til um beinan samanburð á horfum STEMI- og NSTEMI-sjúklinga á heimsvísu. Pó virðast STEMI-sjúklingar almennt hafa verri skammtímahorfur en NSTEMI-sjúklingar en pessi munur finnst ekki í langtímaeftirfylgni, tafla I. ${ }^{12}$

Á Íslandi eru ekki til gögn um langtímahorfur sjúklinga með NSTEMI eða STEMI. Mikilvægt er að meta langtímahorfur pessara sjúklinga í ljósi nýrra greiningarskilmerkja og bættrar meðferðar á síðustu árum. ${ }^{13,14}$ Markmið pessarar rannsóknar var annars vegar að bera saman langtímahorfur NSTEMI- og STEMI-sjúklinga og hins vegar að kanna áhrif áhættupátta á lifun.

\begin{abstract}
Á G R I P
Inngangur: Hratt lækkandi dánartíðni vegna kransæðasjúkdóma á Íslandi helst í hendur við samsvarandi lækkandi nýgengi kransæðastíflu á undanförnum premur áratugum. Markmið pessarrar rannsóknar var að bera saman langtímalifun einstaklinga með NSTEMI (Non-ST elevation myocardial infarction) og STEMI (ST elevation myocardial infarction) og kanna áhrif áhættupátta á lifun.

Efniviður og aðferðir: Rannsóknin náði til allra sjúklinga sem greindust með bráđa kransæðastíflu á Landspítala árið 2006. Upplýsingar um áhættupætti hjarta- og æđasjúkdóma og greiningar voru fengnar úr Sögukerfi spítalans. Sjúklingum var fylgt eftir fram til 1. janúar 2015. Endapunktur rannsóknarinnar var andlát af hvađa orsök sem er. Samsettur endapunktur var dauðsfall eða endurinnlögn vegna kransæðastíflu.

Niðurstöður: Á árinu 2006 greindust 447 einstaklingar með bráđa kransæðastíflu á Landspítala, par af voru 280 með NSTEMI (121.4) og 167 með STEMI (I21 - 121.9). Nýgengi NSTEMI árið 2006 var 91,3 á hverja 100.000 íbúa. Nýgengi STEMI árið 2006 var 55,9 á hverja 100.000 íbúa. Meðalaldur NSTEMI-sjúklinga var 73,0 ár. Konur með NSTEMI voru að meðaltali 8,4 árum eldri en karlar með NSTEMI (konur 78,3 ár og karlar 69,9 ár). Meðalaldur STEMI-sjúklinga var 65,3 ár. Konur með STEMI voru að meðaltali 7,3 árum eldri en karlar með STEMI (konur 70,4 ár og karlar 63 ár). Fimm ára lifun NSTEMI-sjúklinga var 51\%, 42\% meðal kvenna og 57\% međal karla. Fimm ára lifun STEMI sjúklinga var $77 \%, 68 \%$ meðal kvenna og $80 \%$ meðal karla (logrank: $p<0,01)$. Eftir aldursleiðréttingu var marktækt verri langtímalifun eftir NSTEMI samanborið við STEMI.

Ályktanir: Nýgengi NSTEMI var hærra en STEMI á Íslandi árið 2006. Konur höfðu verri langtímahorfur en karlar, sem skýrist af hærri meðalaldri peirra. Langtímalifun NSTEMI-sjúklinga var verri en lifun STEMI sjúklinga prátt fyrir aldursleiðréttingu.
\end{abstract}

doi.org/10.17992//bl.2018.11.203

\section{Efniviður og að̃ferð̄ir}

Rannsóknin var afturskyggn og náði til allra peirra einstaklinga sem greindust með NSTEMI eða STEMI á Landspítala árið 2006. Hluti pessara sjúklinga fékk upphafsmeðferð á sjúkrahúsum og heilsugæslustöðvum á landsbyggðinni og voru síðar sendir á Landspítala til hjartapræðingar, en um petta eru ekki til nákvæmar upplýsingar. Sjúkdómsgreiningar samkvæmt ICD-kóða í tölvukerfi spítalans lágu til grundvallar flokkunar í STEMI (I21.0, I21.1 og I21.9) og NSTEMI (I21.4). Sjúkdómsgreiningar voru endurmetnar út frá fyrirfram ákveðnum skilmerkjum í hverju tilviki fyrir sig. Krafa var gerð um hækkun á trópóníni $\mathrm{T}(<0,01 \mu \mathrm{g} / \mathrm{l})$ og að minnsta kosti $1 \mathrm{~mm}$ hækkun á ST-bili í tveimur samliggjandi leiðslum hjartalínurits eða nýtilkomið vinstra greinrof til að flokk- 
Tafla I. Erlendar lifunarrannsóknir, \%.

\begin{tabular}{|c|c|c|c|c|c|}
\hline & Land & $\begin{array}{l}\text { NSTEMI } \\
4 \text { ára lifun }\end{array}$ & $\begin{array}{l}\text { NSTEMI } \\
5 \text { ára lifun }\end{array}$ & $\begin{array}{l}\text { STEMI } \\
4 \text { ára lifun }\end{array}$ & $\begin{array}{c}\text { STEMI } \\
5 \text { ára lifun }\end{array}$ \\
\hline $\begin{array}{l}\text { PRAIS UK } \\
\text { Registry }^{10}\end{array}$ & Bretland & 77,4 & & & \\
\hline $\begin{array}{l}\text { Fabio Vagnarelli } \\
\text { et } \mathrm{al}^{11}\end{array}$ & Ítalía & & 58 & & 63,6 \\
\hline Vogel et al ${ }^{27}$ & Austurríki & 57,9 & & & \\
\hline Terkelsen et $\mathrm{a}^{9}$ & Danmörk & 50 & & 70 & \\
\hline Pessi rannsókn & Ísland & 55 & 51 & 78 & 77 \\
\hline
\end{tabular}

ast sem STEMI. Sjúklingar með trópónínhækkun án ST-hækkunar á hjartariti voru flokkaðir sem NSTEMI pegar aðrar skýringar á trópónínhækkun höfðu verið útilokaðar. ${ }^{13}$ Peir sem bjuggu erlendis voru útilokaðir. Í peim tilvikum sem sami sjúklingur var greindur með kransæðastíflu oftar en einu sinni árið 2006 réð sú greining sem kom fyrst hópaskiptingunni. Peir sem létust á fyrstu 24 klukkustundunum eftir komu á Landspítala voru útilokaðir í rannsókninni par sem skráning var ekki stöðluð á pví hverjir peirra flokkuðust sem dauðsföll utan sjúkrahúss.

Endapunktur rannsóknarinnar var andlát af hvaða orsök sem er. Sjúklingum var fylgt eftir fram til 1. janúar 2015 og upplýsingar um dánardag voru fengnar frá dánarmeinaskrá Hagstofu, síðar Embættis landlæknis. Samsettur endapunktur samanstóð af andláti af hvaða orsök sem er ásamt endurinnlögn vegna hjartadreps. Upplýsingar um endurinnlagnir vegna hjartadreps (ICD: I21.0, I21.1, I21.9, I21.4) voru fengnar úr sjúkraskrárkerfi Landspítala. Vegna hárrar dánartíðni NSTEMI- og STEMI-sjúklinga fyrsta mánuðinn eftir innlögn voru peir sem létust fyrstu 28 dagana í báðum hópum teknir út fyrir aldursleiðréttingu. Pessi afklipping samsvarar pví að eftirfylgni hefði náð til peirra sem lifðu af hjartaáfallið. Alls voru 34 NSTEMI-sjúklingar og 19 STEMI-sjúklingar teknir út við samanburð vegna pessarra skilmerkja.

Áhættupættirnir háprýstingur, reykingasaga, fjölskyldusaga, blóðfituröskun og sykursýki voru skráðir til að meta áhrif peirra á langtímalifun. Áhættupættir voru skráðir samkvæmt skráningum í Sögukerfi Landspítala. Einstaklingar með háprýsting voru peir sem voru á blóðprýstingslækkandi lyfjum við fyrstu innlögn, höfðu sögu um háan blóðprýsting eða voru greindir með háprýsting í legu. Reykingasögu var skipt upp í tvo flokka, annars vegar peir einstaklingar sem reyktu við innlögn og hins vegar peir sem höfðu aldrei reykt eða höfðu hætt að reykja meira en 30 dögum fyrir innlögn. Blóðfituröskun var skilgreind sem heildarkólesteról í blóði yfir 7,0 mmól/l eða einstaklingar á blóðfitulækkandi lyfjum. Sykursýki var skráð með sömu skilmerkjum og háprýstingur.

Tölfræðileg úrvinnsla var unnin í RStudio (Version 0.98.1091). Nýgengisútreikningar byggðust á fjölda landsmanna 31. desember 2005. Lifunargreiningar voru framkvæmdar til að kanna langtímalifun einstaklinga og Kaplan-Meier gröf teiknuð fyrir bæði NSTEMI og STEMI. Munur milli lifunar NSTEMI og STEMI var metinn með log-rank prófi. Cox-aðhvarfsgreining var notuð til að leiðrétta fyrir aldri, kyni og áhættupáttum. Einpátta- og fjölpátta aðhvarfsgreining voru bæði notuð til að meta áhrif hverrar breytu fyrir sig. T-próf voru notuð til að kanna mun á meðalaldri milli
Tafla II. Lýðfræðilegar upplýsingar rannsóknarpýðis, (\%).

\begin{tabular}{|c|c|c|c|}
\hline & NSTEMI n=280 & STEMI n=167 & p-gildi \\
\hline \multicolumn{4}{|l|}{ Kyn } \\
\hline Karlar & $176(62,9)$ & $117(70,1)$ & \\
\hline Konur & $104(37,1)$ & $50(29,9)$ & n.s. \\
\hline \multicolumn{4}{|l|}{ Meðalaldur (ár) } \\
\hline Alls & 73,0 & 65,3 & $<0,01$ \\
\hline Karlar & 69,9 & 63,1 & $<0,01$ \\
\hline Konur & 78,3 & 70,4 & $<0,01$ \\
\hline \multicolumn{4}{|l|}{ Háprýstingur } \\
\hline Með háprýsting & $195(69,6)$ & $88(52,7)$ & $<0,01$ \\
\hline Án & $63(22,5)$ & $61(36,5)$ & \\
\hline Ópekkt & $22(7,9)$ & $18(10,8)$ & \\
\hline \multicolumn{4}{|l|}{ Reykingasaga } \\
\hline Reykir & $64(22,9)$ & $68(40,7)$ & $<0,01$ \\
\hline Aldrei reykt/hættir & $190(67,9)$ & $85(50,9)$ & $<0,01$ \\
\hline Ópekkt & $26(9,3)$ & $14(8,4)$ & \\
\hline \multicolumn{4}{|l|}{ Fjölskyldusaga } \\
\hline Með sögu & $112(40)$ & $73(43,7)$ & 1 \\
\hline Án sögu & $82(29,3)$ & $55(32,9)$ & \\
\hline Ópekkt & $86(30,7)$ & $39(23,4)$ & \\
\hline \multicolumn{4}{|l|}{ Blóðfituröskun } \\
\hline Með röskun & $122(43,6)$ & $48(28,7)$ & $<0,01$ \\
\hline Án sögu & $86(30,7)$ & $88(52,7)$ & \\
\hline Ópekkt & $72(25,7)$ & $31(18,7)$ & \\
\hline \multicolumn{4}{|l|}{ Sykursýki } \\
\hline Мeð & $60(21,4)$ & $18(10,8)$ & $<0,01$ \\
\hline Án & $162(57,9)$ & $132(79,0)$ & \\
\hline Ópekkt & $58(20,7)$ & $17(10,2)$ & \\
\hline
\end{tabular}

n.s.: ekki tölfræðilega marktækur munur milli hópa

*Peir sem hættu að reykja $\geq 30$ dögum fyrir innlögn töldust vera hættir að reykja

hópa. Kí-kvaðrat próf var notað til að bera saman flokkabreytur. $\mathrm{P}<0,05$ var notað sem mælikvarði á tölfræðilega marktækan mun milli hópa.

Við upphaf rannsóknar lá fyrir leyfi frá vísindasiðanefnd (VSN14-179) og yfirlækni hjartadeildar.

\section{Niðurstöður}

Árið 2006 var 469 sjúklingum gefin sjúkdómsgreiningin bráð kransæðastífla á Landspítala. Í 288 tilvikum var greind NSTEMI og 181 sinni STEMI. Par af voru 7 með NSTEMI og 9 með STEMI útilokaðir vegna búsetu erlendis. Sex einstaklingar greindust bæði með NSTEMI og STEMI árið 2006. Fyrsta greining var NSTEMI hjá 280 einstaklingum og STEMI hjá 167 einstaklingum. Í pessari rannsókn voru pví 447 sjúklingar með bráða kransæðastíflu rannsakaðir. Við samanburð á lifun milli NSTEMI og STEMI voru 246 NSTEMI-sjúklingar sem lifðu af fyrstu 28 dagana og 148 STEMIsjúklingar.

Af rannsóknarhópnum greindust 293 karlar og 154 konur með bráða kransæðastíflu. Lýðfræðilegar upplýsingar og fjöldi áhættupátta rannsóknarpýðisins má sjá í töflu II. Par sem skráning var afturskyggn er um að ræða nokkra vanskráningu áhættupátta. Enginn marktækur munur reyndist á kynjahlutfalli NSTEMI- og STEMI-sjúklinga. 

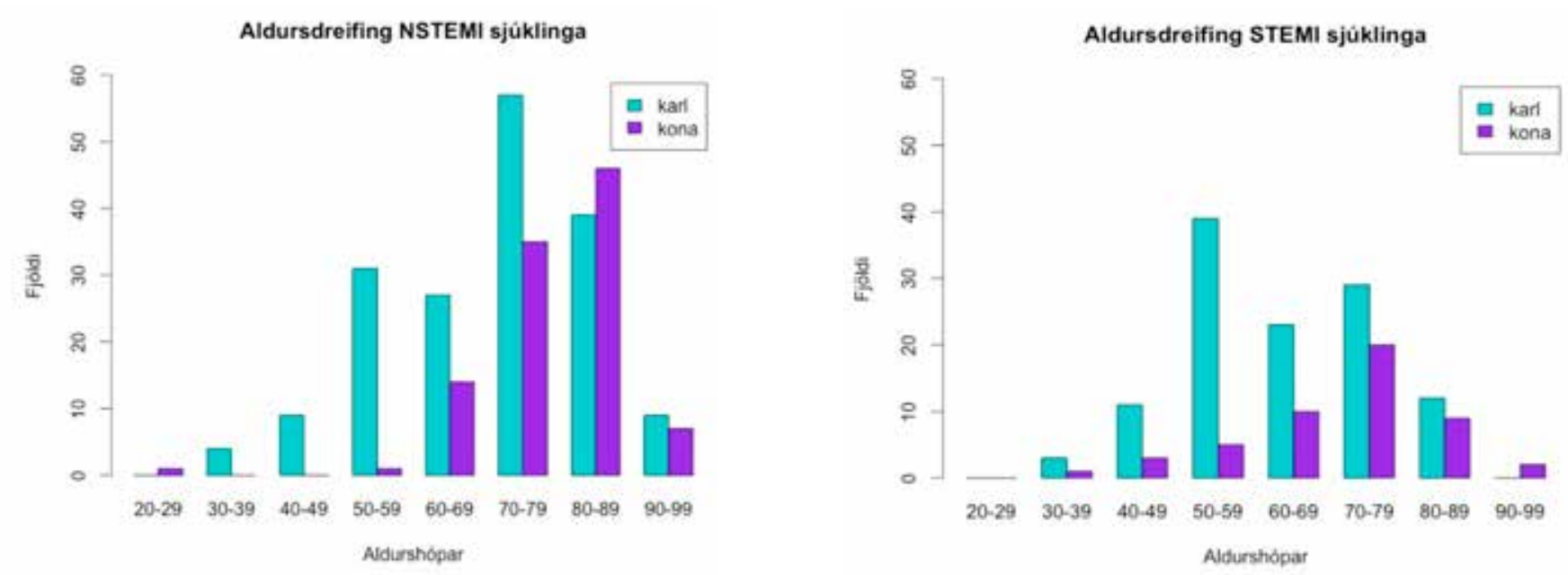

Mynd 1. Gröfin sýna aldursdreifingu kynja peirra sem fengu NSTEMI (vinstra megin) og STEMI (hægra megin). Einstaklingum var skipt í 8 aldurshópa sem sjást á x-ás myndanna.

Tafla III. Klínískir endapunktar, (\%).

\begin{tabular}{llll}
\hline & NSTEMI & STEMI & p-gildi \\
\hline Fjöldi dauðsfalla & $157(56,1)$ & $54(32,3)$ & $<0,01$ \\
\hline $\begin{array}{l}\text { Fjöldi einstaklinga með endurinnlögn vegna } \\
\text { kransæðastíflu }\end{array}$ & $55(19,6)$ & $19(11,4)$ & $<0,02$ \\
\hline $\begin{array}{llll}\text { Samsettur endapunktur } \\
180(64,3)\end{array}$ & $67(40,1)$ & $<0,01$ \\
\hline
\end{tabular}

Nýgengi NSTEMI var 91,3 tilfelli/100.000 íbúa og nýgengi STEMI var 55,9 tilfelli/100.000 íbúa. Meðaleftirfylgni var 4,9 ár/ tilfelli meðal NSTEMI-tilfella og 6,7 ár/tilfelli meðal STEMI-tilfella. Alls létust 157 NSTEMI- (56,1\%) og 54 STEMI-sjúklingar (32,3\%) á rannsóknartímabilinu. Tafla III sýnir klíníska endapunkta dauðsfalla og endurinnlagna vegna kransæðastíflu. Hver sjúklingur er flokkaður einu sinni. Alls voru 74 endurinnlagnir vegna hjartadreps, par af voru 55 (19,6\%) endurinnlagnir meðal NSTEMI-sjúklinga og 19 (11,4\%) endurinnlagnir meðal STEMIsjúklinga $(\mathrm{p}<0,02)$. Alls voru 180 (64,3\%) NSTEMI-sjúklingar og 67
(40,1\%) STEMI sjúklingar sem annaðhvort létust eða fengu aftur kransæðastíflu á tímabilinu.

Mynd 1 sýnir aldursdreifingu fyrir NSTEMI og STEMI. Meðalaldur NSTEMI-sjúklinga var 73,0 ár en 65,3 ár hjá STEMI-sjúklingum. Meðalaldur í NSTEMI-hópnum var 69,9 ár meðal karla og 78,3 ár meðal kvenna $(\mathrm{p}<0,01)$. Meðalaldur í STEMI-hópnum var 63,1 ár meðal karla og 70,4 ár meðal kvenna $(\mathrm{p}<0,01)$. Meðalaldur kvenna var hærri í báđum hópum.

Að 5 árum liðnum frá greiningu NSTEMI voru 51\% á lífi, eða 144 manns. Brottfall NSTEMI-sjúklinga fyrstu 28 dagana eftir greiningu var 12,1\%. Miðgildi lifunar NSTEMI var 5,5 ár, 7 ár hjá körlum og 3,7 ár hjá konum. Í töflu IV má sjá lifun NSTEMI-sjúklinga skipt eftir kyni. Á mynd 2a er sýnd langtímalifun NSTEMIsjúklinga. Mynd 2b sýnir að konur höfðu hærri dánartíðni en karlar (logrank: p=0,022). Áhættuhlutfallið var 1,44 (öryggisbil = 1,05-1,98) sem samsvarar pví að dánartíðni kvenna hafi verið $44 \%$ hærri en hjá körlum. Eftir leiðréttingu fyrir aldri var ekki marktækur munur á lifun milli kynja með NSTEMI par sem konur voru að meðaltali 8,4 árum eldri en karlar $(\mathrm{p}=0,24)$. a

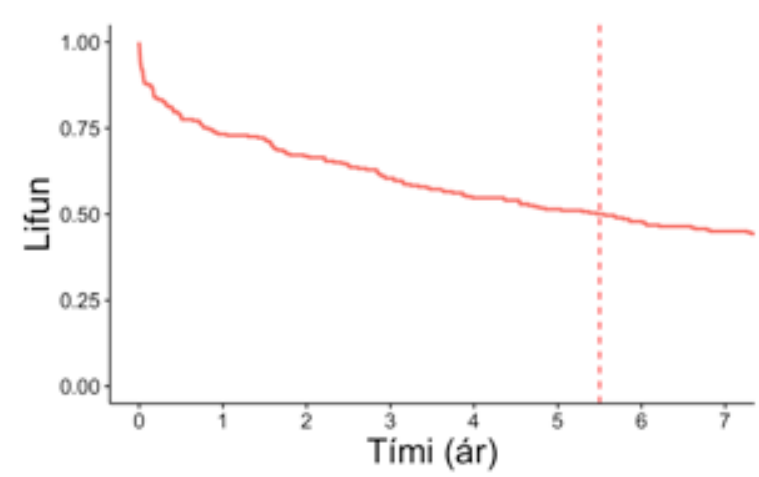

b

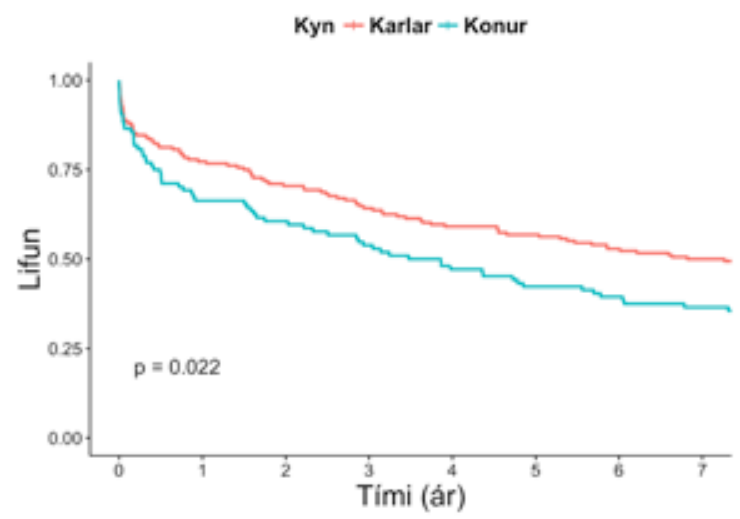

Mynd 2. a. Kaplan-Meier graf sem sýnir hlutfall einstaklinga á lífi á ákveðnum tímapunkti. Rauða punktalínan sýnir pann tímapunkt sem 50\% NSTEMI-sjúklinga eru á lífi eftir 5,5 ár. b. Lifun NSTEMI-sjúklinga skipt upp eftir kyni par sem konur höfðu hærri dánartíðni (Logrank: $p<0,02)$. 
a

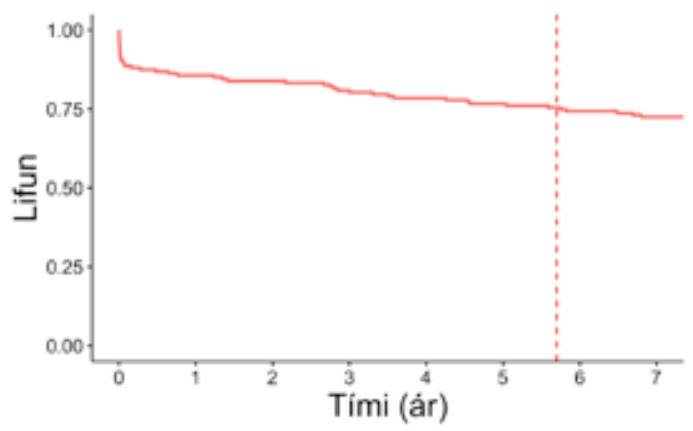

b

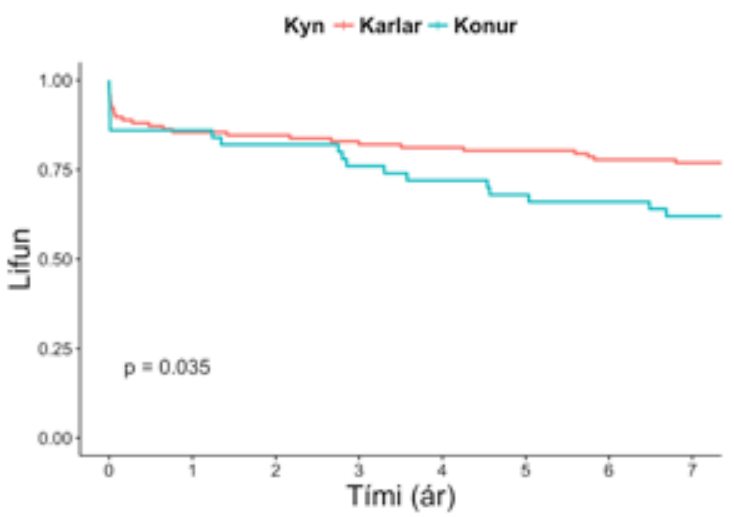

Mynd 3. a. Kaplan-Meier graf sem sýnir hlutfall einstaklinga á lífi á ákveðnum tímapunkti. Rauða punktalínan sýnir pann tímapunkt sem $75 \%$ STEMI-sjúklinga eru á lífi eftir 5,7 ár. b. Lifun STEMI-sjúklinga skipt upp eftir kyni par sem konur höfðu hærri dánartídni (Logrank: p<0,04).

Tafla IV. Lifun NSTEMI-sjúklinga.

\begin{tabular}{lccc}
\hline Ár liðin & Heildarlifun & Lifun karla & Lifun kvenna \\
\hline 1 ár & 0,73 & 0,77 & 0,66 \\
\hline 2 ár & 0,67 & 0,71 & 0,61 \\
\hline 3 ár & 0,60 & 0,64 & 0,54 \\
\hline 4 ár & 0,55 & 0,59 & 0,47 \\
\hline 5 ár & 0,51 & 0,57 & 0,42 \\
\hline 6 ár & 0,48 & 0,53 & 0,39 \\
\hline 7 ár & 0,45 & 0,50 & 0,37 \\
\hline
\end{tabular}

Lifun er sýnd hér sem hlutfall peirra sem eru á lífi á ákveðnum tímapunkti.

Fimm árum eftir greiningu voru 77\% STEMI-sjúklinga á lífi, eða 128 manns. Brottfall STEMI-sjúklinga var hvað mest fyrstu 28 dagana eftir greiningu, eða 11,4\%. Líkt og hjá NSTEMI sést að konur með STEMI hafa verri lifun en karlar (tafla V). Á mynd 3a er sýnd langtímalifun STEMI-sjúklinga. Mynd 3b sýnir að marktækur munur er á lifun karla og kvenna með STEMI á tímabilinu (logrank: $p<0,04)$. Eftir að leiðrétt hefur verið fyrir aldri reynist ekki vera marktækur munur milli kynja $(p=0,84)$.

a

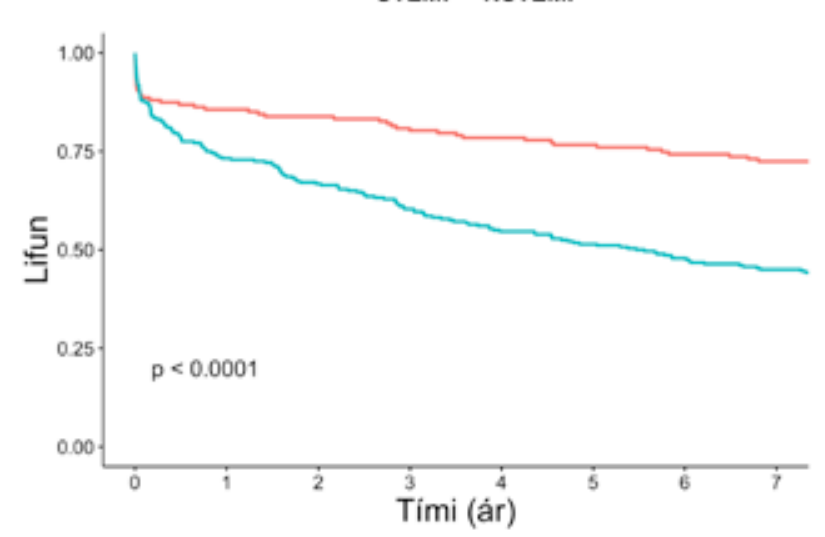

Tafla V. Lifun STEMI-sjúklinga.

\begin{tabular}{lccc}
\hline Ár liðin & Heildarlifun & Lifun karla & Lifun kvenna \\
\hline 1 ár & 0,86 & 0,86 & 0,86 \\
\hline 2 ár & 0,84 & 0,85 & 0,82 \\
\hline 3 ár & 0,80 & 0,82 & 0,76 \\
\hline 4 ár & 0,78 & 0,81 & 0,72 \\
\hline 5 ár & 0,77 & 0,80 & 0,68 \\
\hline 6 ár & 0,74 & 0,78 & 0,66 \\
\hline 7 ár & 0,73 & 0,77 & 0,62 \\
\hline
\end{tabular}

Greinilegur munur er á lifun NSTEMI- og STEMI-sjúklinga eins og sýnt er á mynd 4. Fimm ára lifun NSTEMI sjúklinga var $51 \%$ (42\% meðal kvenna og 57\% meðal karla). Fimm ára lifun STEMI-sjúklinga var 77\% (68\% meðal kvenna og 80\% meðal karla) (log rank: $\mathrm{p}<0,01)$. Mynd 4b sýnir að eftir aldursleiðréttingu er enn marktækur munur á lifun milli NSTEMI og STEMI (ÁH: $1,52 \mathrm{p}=0,02$ ). Einpáttagreining var gerð fyrir hættu á dauðsfalli hjá NSTEMI-sjúklingum með tilliti til aldurs (tafla VI). Öllum pátt-

b

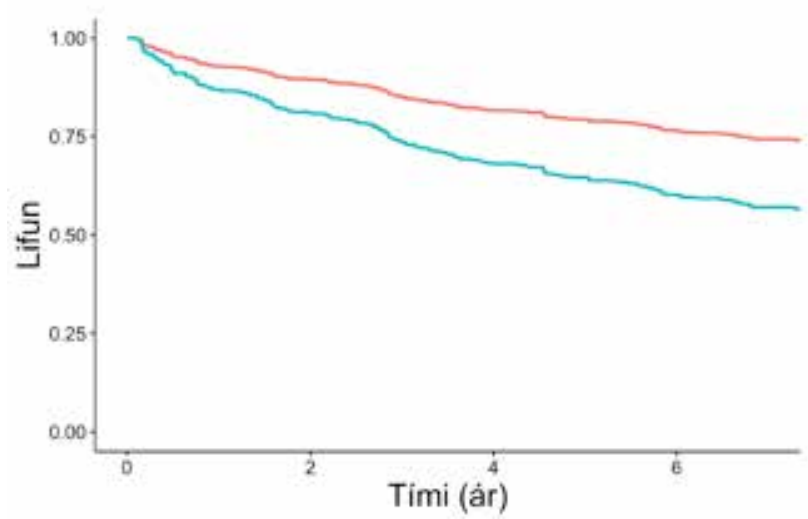

Mynd 4. a. Kaplan-Meier graf sem sýnir langtímalifun pýðisins skipt upp eftir gerð kransæðastíflu, par er töluvert hærri dánartíðni meðal NSTEMI-sjúklinga (logrank: p<0,01). b. Áhrif aldursleiðréttingar á lifun peirra sem lifðu affyrstu 28 dagana. Aldur skýrir ekki mun á lifun NSTEMI og STEMI (Logrank: $p=0,02)$. 
Tafla VI. Aðhvarfsgreining NSTEMI-sjúklinga.

\begin{tabular}{|c|c|c|c|c|c|c|}
\hline \multirow[b]{2}{*}{ Áhrifapættir } & \multicolumn{3}{|c|}{ Einpáttagreining* } & \multicolumn{3}{|c|}{ Fjölpáttagreining } \\
\hline & ÁH & ÖB & p-gildi & ÁH & ÖB & p-gildi \\
\hline Aldur & 1,09 & $(1,07-1,11)$ & $<0,01$ & 1,10 & $(1,08-1,12)$ & $<0,01$ \\
\hline Kyn & 0,82 & $(0,60-1,13)$ & 0,24 & 0,74 & $(0,52-1,06)$ & 0,10 \\
\hline Reykingar & 1,86 & $(1,14-3,04)$ & 0,01 & 1,55 & $(0,98-2,47)$ & $0,06^{* *}$ \\
\hline Sykursýki & 1,89 & $(1,29-2,76)$ & $<0,01$ & 1,42 & $(0,99-2,04)$ & $<0,06^{\star *}$ \\
\hline Háprýstingur & 1,39 & $(0,89-2,18)$ & 0,14 & 1,39 & $(0,93-2,07)$ & 0,11 \\
\hline Fjölskyldusaga & 0,87 & $(0,57-1,33)$ & 0,52 & & 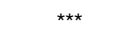 & \\
\hline Blóðfituröskun & 1,37 & $(0,92-2,05)$ & 0,12 & 1,03 & $(0,73-1,45)$ & 0,86 \\
\hline
\end{tabular}

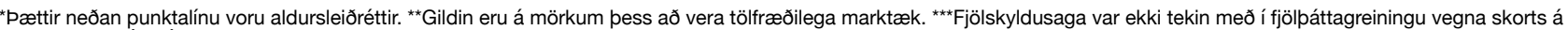
upplýsingum. ÁH: Áhættuhlutfall (Hazard ratio), ÖB: Öryggisbil

Tafla VII. Aðhvarfsgreining STEMI-sjúklinga

\begin{tabular}{|c|c|c|c|c|c|c|}
\hline \multirow[b]{2}{*}{ Áhrifapættir } & \multicolumn{3}{|c|}{ Einpáttagreining ${ }^{\star}$} & \multicolumn{3}{|c|}{ Fjölpáttagreining } \\
\hline & ÁH & ÖB & p-gildi & ÁH & ÖB & p-gildi \\
\hline Aldur & 1,12 & $(1,09-1,15)$ & $<0,01$ & 1,12 & $(1,09-1,17)$ & $<0,01$ \\
\hline Kyn & 0,94 & $(0,54-1,65)$ & 0,84 & 0,99 & $(0,52-1,88)$ & 0,98 \\
\hline Reykingar & 1,46 & $(0,74-2,88)$ & 0,27 & 1,18 & $(0,61-2,27)$ & 0,63 \\
\hline Sykursýki & 3,30 & $(1,55-7,02)$ & $<0,01$ & 2,36 & $(1,04-5,35)$ & 0,04 \\
\hline Háprýstingur & 2,12 & $(1,02-4,43)$ & $<0,05$ & 1,32 & $(0,70-2,48)$ & 0,39 \\
\hline Fjölskyldusaga & 1,10 & $(0,49-2,50)$ & 0,81 & & $\star *$ & \\
\hline Blóðfituröskun & 1,46 & $(0,70-3,03)$ & 0,31 & 0,87 & $(0,46-1,67)$ & 0,68 \\
\hline
\end{tabular}

*Pættir neđan punktalínu i einpáttagreiningu voru aldursleiđréttir. **Fjölskyldusaga var tekin ekki tekin með í fjölpáttagreiningu vegna skorts á upplýsingum. ÁH: Áhættuhlutfall (Hazard ratio), ÖB: Öryggisbil

um neðan punktalínunnar var bætt einum og sér í líkanið sem gaf áhættuhlutföllin sem skráð eru. Sömu aðferð var beitt fyrir STEMI-sjúklinga (tafla VII). Áhætta á andláti á tímabilinu jókst um 9\% fyrir hvert aldursár meðal NSTEMI-sjúklinga og 12\% meðal STEMI-sjúklinga. Einstaklingar með sykursýki höfðu marktæka áhættuaukningu bæði meðal NSTEMI- og STEMI-sjúklinga og reykingar juku áhættu um $86 \%$ meðal NSTEMI-sjúklinga.

Tafla VI sýnir áhættuhlutföll dauðsfalla sem fengust úr fjölpáttagreiningu fyrir NSTEMI. Reykingar juku áhættu um 55\% en pað var á mörkum pess að vera tölfræðilega marktækt $(\mathrm{p}=0,06)$. Sykursýki sýndi einnig áhættuaukningu um 42\% ( $p<0,06)$. Fjölpáttalíkan fyrir STEMI má sjá í töflu VII. Sykursýki jók áhættu á andláti á tímabilinu um 136\%. Aðrir áhættupættir höfðu ekki marktæk tengsl við lifun.

\section{Umræða}

Á undanförnum árum hefur nýgengi kransæðasjúkdóma verið að lækka á Íslandi. Á sama tíma hefur greiningin orðið nákvæmari með hánæmum trópónín-T-mælingum pannig að smærri hjartavöðvadrep greinast oftar en ádur. Pessi aukna nákvæmni í greiningu á sennilega pátt í pví að hlutfall NSTEMI af öllum hjartaáföllum hefur verið að aukast á kostnað STEMI. Í rannsókn okkar var nýgengi NSTEMI (91,3/100.000 íbúa) hærra en STEMI (55,9/100.000 íbúa) á Íslandi árið 2006. Fáar rannsóknir hafa birt nýgengi í svip- uðu pýði par sem flestar eru með fyrirfram valin inntökuskilyrði sem endurspeglar oft á tíðum ekki almennt pýði. Í Svípjóð er nýgengi STEMI 66/100.000 íbúa á ári og er talið að pað endurspegli raunverulegt nýgengi par sem SWEDEHEART gæðaskráin nær til allra sjúkrahúsa sem meðhöndla bráða kransæðastíflu í Svípjóð. ${ }^{14}$ Svipaðar tölur hafa verið birtar í rannsóknum í Bandaríkjunum, Belgíu og Tékklandi. ${ }^{15}$ Íslenskar tölur benda til pess að nýgengi blóðpurrðarsjúkdóma sé lágt miðað við önnur lönd. ${ }^{8,16}$ Margvíslegar ástæður gætu legið að baki, til að mynda mismunur á tíðni áhættupátta og aldursdreifingu pjóða.

Almennt orsakast STEMI af hjartavöðvadrepi sem nær í gegnum alla pykkt hjartavöðvans og veldur umfangsmeira hjartavöðvadrepi en NSTEMI. STEMI leiða pannig oftar til hjartabilunar sem hefur neikvæð áhrif á horfur. Pess vegna er rökrétt að álykta að horfur STEMI-sjúklinga ættu almennt að vera verri en horfur NSTEMI-sjúklinga. Í rannsókn okkar kom í ljós að pessu var pveröfugt farið. Alls létust 157 NSTEMI- (56,1\%) og 54 STEMI-sjúklingar (32,3\%) á rannsóknartímabilinu.

Fimm ára lifun NSTEMI sjúklinga var 51\% en fimm ára lifun STEMI sjúklinga var $77 \%$.

Meðalaldur NSTEMI-sjúklinga var 7,7 árum hærri en meðalaldur STEMI-sjúklinga. •að reyndist vera marktækur munur á lifun milli NSTEMI og STEMI prátt fyrir aldursleiðréttingu sem gefur til kynna að aldur útskýri ekki pann mun á lifun hópanna. Petta er í samræmi við niðurstöður erlendra rannsókna sem sýna að 
svo virðist sem NSTEMI-sjúklingar hafi að meðaltali útbreiddari kransæðasjúkdóm en peir sem fá STEMI. ${ }^{17}$ Einnig er hærri tíðni endurkomu hjartadreps meðal NSTEMI-sjúklinga sem hefur neikvætt forspárgildi á lifun. ${ }^{18}$

Munur er á aldri og flestum áhættupáttum milli NSTEMI- og STEMI-sjúklinga í pessari rannsókn, sem bendir til tveggja ólíkra hópa eða mismunandi birtingarmyndar kransæðasjúkdóms. Tafla 1 sýnir samanburð á erlendum rannsóknum í löndum Evrópu. Dönsk rannsókn tók til lifunar NSTEMI- og STEMI-sjúklinga sem greindir voru á árunum 1999-2001 sem sýndi fram á sambærilegar langtímahorfur og pessi rannsókn. ${ }^{9}$

Konur höfðu marktækt verri lifun en karlar, hvort sem pær greindust með NSTEMI eða STEMI. Konur voru 7-8 árum eldri að meðaltali í báðum hópum (tafla II). Eftir aldursleiðréttingu reyndist ekki vera munur á lifun kynjanna. Pví má ætla að aldursmunurinn hafi að miklu leyti útskýrt pann mun í lífslíkum sem sást á milli kynjanna. Aldurdreifing kynja er sambærileg og sést erlendis par sem meðalaldur kvenna er hærri meðal NSTEMI- og STEMI-sjúklinga. ${ }^{19,20}$ Pekkt er að konur fá hjarta- og æðasjúkdóma að meðaltali 6-10 árum seinna á lífsleiðinni en karlar. Pessi mismunur eyðist hjá konum sem eru með sykursýki. ${ }^{21}$ Eftir tíðahvörf kvenna eykst nýgengi hjarta- og æðasjúkdóma. ${ }^{22}$ Euroheart-rannsóknin hefur sýnt að eldri sjúklingar eru líklegri til að fá NSTEMI fremur en STEMI, hafa töluvert hærri dánartíðni í spítalalegu og eru meðhöndlaðir með færri inngripum. ${ }^{23}$

Við leiðréttingu fyrir aldri kom í ljós að reykingar höfðu neikvætt forspárgildi lifunar meðal NSTEMI-sjúklinga. Meðal STEMI- sjúklinga reyndist ekki vera marktækur munur á lifun peirra sem reyktu og peirra sem reyktu ekki. Petta er í samræmi við erlendar rannsóknir sem hafa sýnt fram á að reykingamenn hafa í sumum tilvikum jafngóðar eða betri horfur eftir hjartaáfall en peir sem ekki reykja (smoking paradox). ${ }^{24,25}$ Peir sem reykja eru líklegri til að látast fyrr vegna ýmissa annarra sjúkdóma sem gæti haft áhrif á horfur reykingamanna í pessari rannsókn. Erlendar rannsóknir hafa sýnt fram á hærri tíðni sykursýki meðal NSTEMIsjúklinga líkt og sást í pessari rannsókn. ${ }^{9}$ Hærri tíðni sykursýki gæti mögulega átt pátt í verri lifun par sem sykursýki eykur oxunarálag á æðar líkamans og hraðar ferli æðakölkunar. ${ }^{26}$
Í pessari rannsókn er lýst langtímahorfum sjúklinga með bráða kransæðastíflu á Íslandi árið 2006. Niðurstöður eru að mörgu leyti sambærilegar við pað sem sést hefur í erlendum rannsóknum. Nýgengi NSTEMI hefur farið hækkandi á undanförnum árum og er hærra í rannsókn okkar en nýgengi STEMI. Konur eru marktækt eldri en karlar og sé leiðrétt fyrir aldri skýrast verri horfur peirra af pessum aldursmun. Hins vegar skýrir aldursmunur ekki verri horfur NSTEMI-sjúklinga samanborið við pá sem hafa STEMI. Horfur sjúklinga með bráða kransæðastíflu hafa farið batnandi frá peim tíma sem pessi rannsókn nær til, árinu 2006. Par koma annars vegar til breytt staða helstu áhættupátta kransæðasjúkdóms en líka markvissari notkun verndandi meðferðar og inngripa. ${ }^{6}$ Ljóst er að sykursýki er nú sem fyrr einn sterkasti áhrifavaldur aukinnar áhættu hjá sjúklingum með kransæðasjúkdóm.

Peirri spurningu er enn ósvarað hvað skýrir pann mismun á horfum NSTEMI- og STEMI-sjúklinga sem fram kemur í pessari rannsókn. Til pess að greina pá pætti sem liggja að baki pyrfti stærri rannsókn sem nær yfir meðferðarleiðir og fleiri pætti sem ekki eru greindir hér. Рað verður viðfangsefni síðari tíma rannsókna. Hins vegar bendir margt til pess að birtingarmyndir og horfur bráðra kransæðaheilkenna séu margpættar og háðar breytilegum áhrifapáttum í umhverfi og meðferð.

Túlka ber niðurstöður okkar með nokkurri varúð af eftirtöldum ástæðum: Rannsóknarbýðið er lítið og nær einungis til eins árs. Rannsóknin nær eingöngu til peirra sjúklinga sem lögðust inn á Landspítala með bráða kransæðastíflu árið 2006 og tekur pví ekki tillit til sjúklinga sem lágu inni á Fjórðungssjúkrahúsinu á Akureyri eða öðrum heilbrigðisstofnunum landsins. Á peim tíma sem rannsóknin nær til, árinu 2006, voru ekki notaðar hánæmar trópónín-T-mælingar (hs-TnT) á Landspítala eins og síðar varð. Pess vegna er óljóst að hve miklu leyti aukið næmi pessara prófa hefur leitt til aukningar á greiningu NSTEMI á kostnað hvikullar hjartaangar. Dánarorsakir voru ekki skráðar og hlutfall bráðrar kransæðastíflu sem dánarorsakar er pví ópekkt. Um afturskyggna áhorfsrannsókn er að ræða sem leiðir til pess að upplýsingar um áhættupætti eru ófullkomnar. Hins vegar er eftirfylgni nákvæm hvað varðar dauðsföll og endurtekin hjartaáföll. 


\section{Heimildir}

1. Ezzati M, Obermeyer Z, Tzoulaki I, Mayosi BM, Elliott P, Leon DA. Contributions of risk factors and medical care to cardiovascular mortality trends. Nat Rev Cardiol 2015;12: 508-30.

2. Laslett LJ, Alagona PJ, Clark BA 3rd, Drozda JPJ, Saldivar $\mathrm{F}$, Wilson $\mathrm{SR}$, et al. The worldwide environment of cardiovascular disease: prevalence, diagnosis, therapy, and policy issues: a report from the American College of Cardiology. J Am Coll Cardiol 2012; 60(25 Suppl): S1-49.

3. WHO । Cardiovascular diseases (CVDs). WHO - 2017.

4. Nichols M, Townsend N, Scarborough P, Rayner M Cardiovascular disease in Europe 2014: epidemiological update. Eur Heart J 2014; 35: 2950-9.

5. Andersen K, Aspelund T, Guðmundsson EF, Siggeirsdóttir K, Pórólfsdóttir RB, Sigurðsson G, et al. Yfirlitsgrein. Ú gögnum Hjartaverndar: Faraldsfræði kransæðasjúkdóma á Íslandi í hálfa öld Læknablaðið 2017; 103: 411-20.

6. Andersen $\mathrm{K}$, Jóhannesdóttir $\mathrm{BK}$, Kristjánsson JM Gudnason T. Decreasing case fatality in myocardial infarction is explained by improved medical treatment. Acta Cardiol 2011; 66: 39-46.

7. Aspelund T, Gudnason V, Magnusdottir BT, Andersen K, Sigurdsson G, Thorsson B, et al. Analysing the large decline in coronary heart disease mortality in the icelandic population aged 25-74 between the years 1981 and 2006 PLoS One. 2010; 5 : 1-8.

8. Yeh RW, Sidney S, Chandra M, Sorel M, Selby J V, Go AS. Population trends in the incidence and outcomes of acute myocardial infarction. N Engl J Med 2010; 362: 2155-65.

9. Terkelsen CJ, Lassen JF, Norgaard BL, Gerdes JC, Jensen $\mathrm{T}$, Gotzsche LB-H, et al. Mortality rates in patients with ST-elevation vs. non-ST-elevation acute myocardial infarction: observations from an unselected cohort. Eur Heart J 2005; 26: 18-26.

10. Taneja AK, Collinson J, Flather MD, Bakhai A, de Arenaza $\mathrm{DP}$, Wang D, et al. Mortality following non-ST elevation acute coronary syndrome: 4 years follow-up of the PRAIS UK Registry (Prospective Registry of Acute Ischaemic Syndromes in the UK). Eur Heart J 2004; 25: 2013-8.

11. Vagnarelli $F$, Taglieri $N$, Ortolani $P$, Norscini G, Cint L, Bacchi Reggiani ML, et al. Long-Term Outcomes and Causes of Death After Acute Coronary Syndrome in Patients in the Bologna, Italy, Area. Am J Cardiol 2018; 115: 171-7.
12. Pilgrim T, Vranckx P, Valgimigli M, Stefanini GG, Piccolo $\mathrm{R}$, Rat J, et al .Risk and timing of recurrent ischemic events among patients with stable ischemic heart disease, non-ST-segment elevation acute coronary syndrome, and ST-segment elevation myocardialinfarction. Am Heart J 2016; 175: 56-65.

13. Roffi M, Patrono C, Collet J-P, Mueller C, Valgimigli M, Andreotti F, et al. 2015 ESC Guidelines for the management of acute coronary syndromes in patients presenting without persistent ST-segment elevation: Task Force for the Management of Acute Coronary Syndromes in Patients Presenting without Persistent ST-Segment Elevation of th. Eur Heart J 2016; 37: 267-315.

14. Ibanez B, James S, Agewall S, Antunes MJ, BucciarelliDucci C, Bueno H, et al. 2017 ESC Guidelines for the management of acute myocardial infarction in patients presenting with ST-segment elevation: The Task Force for the management of acute myocardial infarction in patients presenting with ST-segment elevation of the European Society. Eur Heart J 2018; 39: 119-77.

15. Widimsky P, Wijns W, Fajadet J, de Belder M, Knot J, Aaberge L, et al. Reperfusion therapy for ST elevation acute myocardial infarction in Europe: description of the current situation in 30 countries. Eur Heart J 2010; 31: 94357.

16. McManus DD, Gore J, Yarzebski J, Spencer F, Lessard D, Goldberg RJ. Recent trends in the incidence, treatment, and outcomes of patients with STEMI and NSTEMI. Am J Med 2011; 124: 40-7.

17. van Leeuwen MAH, Daemen J, van Mieghem NM, de Boer SPM, Boersma E, van Geuns RJ, et al. Comparison of longterm outcomes in STEMI and NSTE-ACS after coronary stent placement: an analysis in a real world BMS and DES population. Int J Cardiol 2018; 167: 2082-7.

18. Armstrong $\mathrm{PW}, \mathrm{Fu} Y$, Chang WC, Topol EJ, Granger $\mathrm{CB}$ Betriu A, et al. Acute coronary syndromes in the GUSTOIIb trial: prognostic insights and impact of recurrent ischemia. The GUSTO-IIb Investigators. Circulation 1998; 98: 1860-8.

19. Sulo G, Vollset SE, Nygard O, Igland J, Egeland GM Ebbing $\mathrm{M}$, et al. Trends in acute myocardial infarction event rates and risk of recurrences after an incident event in Norway 1994 to 2009 (from a Cardiovascular Disease in Norway Project). Am J Cardiol 2014; 113:-1777-81.
20. Wagner A, Arveiler D, Ruidavets JB, Bingham A, Montaye $\mathrm{M}$, Ferrieres J, et al. Gender- and age-specific trends in coronary heart disease mortality in France from 2000 to 2007: results from the MONICA registers. Eur J Prev Cardiol 2014; 21: 117-22.

21. Huxley R, Barzi F, Woodward M. Excess risk of fatal coronary heart disease associated with diabetes in men and women: meta-analysis of 37 prospective cohort studies. BMJ Br Med J 2006; 332: 73-8

22. Hulley S, Grady D, Bush T, Furberg C, Herrington D, Riggs B, et al. Randomized trial of estrogen plus progestin for secondary prevention of coronary heart disease in postmenopausal women. Heart and Estrogen/progestin Replacement Study (HERS) Research Group. JAMA 1998; 280: 605-13.

23. Rosengren A, Wallentin L, Simoons M, Gitt AK, Behar S, Battler A, et al. Age, clinical presentation, and outcome of acute coronary syndromes in the Euroheart acute coronary syndrome survey. Eur Heart J 2006; 27: 789-95.

24. Gupta T, Kolte D, Khera S, Harikrishnan P, Mujib M, Aronow WS, et al. Smoker's Paradox in Patients With ST-Segment Elevation Myocardial Infarction Undergoing Primary Percutaneous Coronary Intervention. J Am Heart Assoc 2016; 5.

25. Gennaro G, Brener SJ, Redfors B, Kirtane AJ, Généreux $\mathrm{P}$, Maehara A, et al. Effect of Smoking on Infarct Size and Major Adverse Cardiac Events in Patients With Large Anterior ST-Elevation Myocardial Infarction (from the INFUSE-AMI Trial). Am J Cardiol 2016; 118: 1097-104.

26. Galkina E, Ley K. Immune and Inflammatory Mechanisms of Atherosclerosis. Annu Rev Immunol 2009; 27: 165-97.

27. Vogel B, Hahne S, Kozanli I, Kalla K, Jarai R, Freynhofer $\mathrm{M}$, et al. Influence of updated guidelines on short- and long-term mortality in patients with non-ST-segment elevation acute coronary syndrome (NSTE-ACS). Int J Cardiol 2018: 159: 198-204

Barst til blađsins 5. maí 2018 , sampykkt til birtingar 21. október 2018.

\section{Long-term survival of patients with acute myocardial infarction in Iceland}

\section{Einar Logi Snorrason \\ Bergrós Kristín Jóhannesdóttir \\ Thor Aspelund \\ Vilmundur Gudnason \\ Karl Andersen}

Introduction: Despite the decreasing incidence rate of acute coronary syndromes worldwide, the incidence of NSTEMI (NonST elevation myocardial infarction) has increased relative to STEMI (ST elevation myocardial infarction). The aim of this study was to compare long-term survival rates of NSTEMI and STEM patients and to explore the effects of risk factors on survival. Material and methods: All patients hospitaized for acute myocardial infarction at Landspitali University Hospital during the calendar year of 2006 were included in the study. Information about risk factors was obtained using electronic medical records. The primary endpoint was all cause mortality, the secondary endpoint was defined as death or myocardial infartion. Patients were followed up to January 1st 2015.
Results: Among 447 patients diagnosed with acute myocardia infarction in Iceland in 2006, 280 patients were diagnosed with NSTEMI (121.4) and 167 with STEMI (I21, 121.9). NSTEMI and STEMI incidence rates per 100.000 inhabitants in Iceland were 91.3 and 55.9, respectively. The mean age of NSTEMI patients was 73.0 years, women were on average 8.4 years older than men. The mean age of STEMI patients was 65.3 years, women were on average 7.3 years older than men. The five-year survival rate for NSTEMI patients was $51 \%, 42 \%$ among women and $57 \%$ among men. The five-year survival rate for STEMI patients was $77 \%, 68 \%$ among women and $80 \%$ among men. Five year age-adjusted survival rates were higher for STEMI than NSTEMI (logrank: $p<0.01$ ).

Conclusion: The incidence of NSTEMI was higher than that of STEMI in Iceland in 2006. The worse prognosis of women as compared to men was due to the higher mean age of women. Overall, long-term survival of NSTEMI patients was worse than that of STEMI patients even after adjustment for difference in age.

Key words: acute myocardial infarction, prognosis, long term survival, ST elevation myocardial infarction, Non ST elevation myocardial infarction.

Correspondence: Karl Andersen, andersen@landspitali.is 